\title{
Epipalaeolithic and Pre-Pottery Neolithic burials from the north Lebanese highlands in their regional context
}

\section{Andrew Garrard ${ }^{1}$, Yvonne Edwards ${ }^{1}$, Jay Stock ${ }^{2}$ and Corine Yazbeck $^{3}$}

Archaeological human remains and their funerary contexts provide valuable insights into social and ideological lives as well as the origins, health and activities of past communities. In the southern Levant extensive cemeteries from the Late Epipalaeolithic (Natufian) and Pre-Pottery Neolithic (PPN) have been recognized, although burials from earlier periods are sparse. Elsewhere in the Levant the record from the whole Epipalaeolithic is poor. Excavations at two adjacent caves at Moghr el-Ahwal in the Qadisha Valley of northern Lebanon have provided a window into human lives and mortuary practices from an otherwise poorly known region. This includes material from contexts with radiocarbon dates ranging from the late Kebaran, Geometric Kebaran and Natufian (c. 19-13.8 ka cal BP) as well as directly dated skeletal material from the mid to late Pre-Pottery Neolithic B (c. 9.9-9.5 ka cal BP). Although this forested mountain area may have been isolated from other regions in the Levant, the burial practices show links to the wider area.

\section{Keywords}

Epipalaeolithic, Pre-Pottery Neolithic, Levant, Lebanon, burial practices, Moghr el-Ahwal

\footnotetext{
${ }^{1}$ Institute of Archaeology, University College London, UK

${ }^{2}$ Department of Archaeology and Anthropology, Cambridge, UK

${ }^{3}$ Lebanese University, Beirut, Lebanon

Andrew Garrard (Corresponding author) Institute of Archaeology, University College London, 31-34 Gordon Square, London WC1H OPY: e-mail: a.garrard@ucl.ac.uk
} 


\section{Introduction}

Knowledge of late Palaeolithic and early Neolithic mortuary practices in the Levant continues to grow, providing a better appreciation of the social and ideological lives of these communities and how they viewed, treated and related to their ancestors. The human remains also provide invaluable information on issues such as morphological evolution, the population history of the area, diet and health, as well as the routine activities of individuals which have impacted on their bone morphology (Belfer-Cohen 1995; Bocquentin 2003; Bocquentin and Garrard 2016; Boyd 2001; Byrd and Monahan 1995; Croucher 2012; Faerman et al 2007; Goring-Morris and Belfer-Cohen 2014; Kuijt 2000; Maher et al 2012; Nadel 1994; Perrot and Ladiray 1988). However within the Levant, the burial record of the Epipalaeolithic and PrePottery Neolithic of Lebanon has remained very poorly known. The situation has recently improved with the discovery of a range of human remains in various burial and depositional contexts at the Moghr el-Ahwal caves situated in the Qadisha Valley of north-west Lebanon (Garrard \& Yazbeck 2004; 2008; 2013). These are described in this article and compared to examples of mortuary practice and the osteo-archaeological record from the wider Levantine region.

\section{Context}

The landscape of Lebanon is dominated by two parallel mountain ranges: the high and rugged Mount Lebanon chain in the west, which is separated from the Mediterranean by a narrow coastal plain, and the Anti-Lebanon Mountains and Mount Hermon in the east which border the Syrian plateau. Today, the coastal mountains receive amongst the highest winter rainfall in the eastern Mediterranean and are heavily forested in undisturbed areas. In 2003 a major field project was initiated in the Qadisha Valley of north-west Lebanon to examine the settlement history and environments of the region through the late Pleistocene and early Holocene. The survey identified several caves and rock shelters as well as open air sites with prehistoric deposits in the lower mountain belt $(500-800 \mathrm{~m})$ particularly between the Qadisha Valley and the Nahr Asfour (Garrard and Yazbeck 2004). Most notable amongst these was a group of three adjacent caves in an elevated rock crag near to the village of Moghr el-Ahwal (Fig. 1). Excavations of two of these caves exposed layers of occupation spanning various phases of the Epipalaeolithic and the Neolithic and a diversity of finds including flaked and ground stone industries, bone tools, shell beads and quantities of animal bones (Edwards et al 
2017; Garrard \& Yazbeck 2008; 2013). Of particular note was the discovery of human remains in various depositional contexts and it is these which form the major focus of the current paper.

Prior to these discoveries, the only anatomically modern human remains from late Palaeolithic contexts in Lebanon, had come from three localities just north of Beirut and a fourth in the Beqaa Valley. The earliest were a juvenile skeleton, and part of a maxilla from Ksar Akil which were dated to the Initial and Early Upper Palaeolithic (Fig. 1) (Bergman and Stringer 1989; Douka et al. 2013; Metni 1999; Waechter 1975). The second and third were two skeletons from Early or Middle Epipalaeolithic levels at Abri Bergy and a foetus from Late Epipalaeolithic or Neolithic levels at Antelias (Copeland and Wescombe 1965; Vallois 1957; Waechter 1975). The fourth locality was the Late Epipalaeolithic Natufian site of Saaidé in the Beqaa Valley where a single burial was found under a limestone boulder mortar (Schroeder 1991; Solivères 1975-77). In relation to the Pre-Pottery Neolithic, the only recorded skeletal remains until recently were those from late PPNB Tell Labwé South in the Beqaa Valley (Copeland and Yazbeck 2002; Haïdar-Boustani and Ibáñez 2011; Kirkbride 1969), however new so far unpublished burials have been discovered at Tabarja just $20 \mathrm{~km}$ north of Beirut (Yazbeck p.c.). Unfortunately with the exception of the finds from Ksar Akil, the material from the earlier excavated sites is very poorly published and it is uncertain how many of the skeletal remains are still available for study.

The archaeological investigations at the Moghr el-Ahwal (MEA) Caves, their environmental context and radiocarbon dating have been described in detail by Garrard and Yazbeck $(2004 ; 2008 ; 2013)$ and only a brief description of the site and excavations is given here. The caves are located in the Timsah rock, a c. $80 \mathrm{~m}$ long natural limestone formation, located at c. $620 \mathrm{~m}$ elevation, in a topographically sheltered position overlooking the Qadisha ravine and c. $400 \mathrm{~m}$ east of Moghr el-Ahwal village. Cave 1 was a natural archway and is now used as an access route to an adjacent house and was not excavated. Excavation of Caves 2 and 3 took place during 2004-5 and 2008. The distance between the two cave entrances is c. $18 \mathrm{~m}$ over rising ground.

Cave 2, which is the smallest, comprises a low south-facing rock shelter leading to an inner chamber with a second very small entrance on the north side of the rock. Excavation took place across a $30 \mathrm{sq} \mathrm{m}$ area (grid shown in Fig. 2), where the depth of archaeological deposits was only $50 \mathrm{~cm}$ but comprised 43 separate loci, spanning six phases of occupation (F to A) (Garrard and Yazbeck 2008: 2013). The deposits were held in place by a raised bedrock-sill across the front of the cave. The stratigraphy revealed Epipalaeolithic and Neolithic phases which in part overlaid earlier undated deposits. Radiocarbon dates are presented in Table 1. Those most relevant to the burials include firstly an AMS date on charcoal of c. $15.2-14.6 \mathrm{ka}$ 
cal BP (to $2 \sigma$ ) from a burial pit (locus 30) which contained a rich Geometric Kebaran (Middle Epipalaeolithic) tool assemblage. Secondly two direct dates on human bone of c. $9.9-9.5 \mathrm{ka} \mathrm{cal}$ $\mathrm{BP}$ were obtained from a separate series of burial pits at the opposite end of the rock shelter (locus 18). These dates were obtained using ultrafiltration AMS techniques and would suggest a late-Middle to early-Late Pre-Pottery Neolithic B (PPNB) age, although no diagnostic lithics of this time-frame were found in association within the deposits.

Cave 3 is a substantially larger cave opening at the south-eastern end of Timsah Rock. This leads into an enclosed fissured area open to the sky and to a small entrance on the northern side. Here four areas were excavated (the grids of areas B, C and D are shown in Fig. 2) of which the best preserved was Area $\mathrm{C}$. The latter was excavated to a depth of $1.3 \mathrm{~m}$ revealing six phases of occupation (F to A), comprising 64 separate loci (Garrard and Yazbeck 2008; 2013). It should be noted that because of the difficulties of correlation, a separate phasing system was used in each cave. The three lowest occupation phases in Cave 3 Area $\mathrm{C}$ provided a series of AMS dates from charcoal (Table 1). In order, from the lowest to the highest, these were: Phase

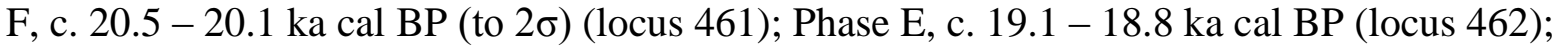
Phase D, 16.6 - 15.8 ka cal BP (locus 456) which would suggest a sequence from Kebaran to Geometric Kebaran (Early to Middle Epipalaeolithic). These early levels were overlain by various features which appeared to be Early Natufian (early Late Epipalaeolithic) in date including a shallow pit with a fill dated by charcoal to c. $14.5-13.8 \mathrm{ka}$ cal BP (Phase C1; locus 442). It should be noted that despite the radiocarbon dates, the lithic material found in each of these phases was dominated by Geometric Kebaran forms. It is possible that this was the most extensive period of occupation and that taphonomic processes led to some penetration of material into both earlier and later levels.

Traces of later phase activities including Pottery Neolithic, Early Bronze Age and historic periods were encountered in both caves but are not discussed in this paper.

\section{Human remains from Cave 2}

\section{Skeletal Remains from Phases E to C}

The earliest phases, which remain undated, provided little evidence of burial activities although a single adult hallux phalanx 1 and a neonatal vertebral arch were recovered from Phase E, locus 5, square V (Table 2).

On the eastern side of the cave entrance, immediately behind a high bedrock sill which runs across the cave-mouth, excavation in the Geometric Kebaran levels of Phase D revealed a 
well-defined burial pit in locus 30, square Y, which contained a partial, adult skeleton. Figure 3 shows the pit in an early phase of excavation with leg bones emerging from the fill. The skeletal remains lay in situ but were incomplete and comprised only bones of the left and right leg. These included the distal extremity of the femur, patella, tibia, fibula, astragalus, calcaneum, other tarsals and one phalanx of the left leg, together with the distal halves of the tibia and fibula and a fragment of the proximal articulation of the right leg (Table 2). All surviving long bone epiphyses were fused and the disposition of the bones indicated that these were articulated at the time of burial.

Both tibiae and fibulae had been broken in situ but it was possible to re-join most fragments and Fig. 4 shows the surviving bones from both legs. The left tibia could be almost completely reconstructed and the right partly reconstructed, allowing some morphometric analysis. Both long-bones and fibulae were also CT (X ray Computed Tomography) scanned and Fig. 5 shows scans of the right and left tibia/fibula, omitting the fractured condylar ends. The left tibia length and the position of the nutrient foramen are listed in Table 3 along with a comparison of length data from Ohalo II (Hershkovitz et al 1995), Kharaneh IV (Rolston 1982), Wadi Mataha (Stock et al. 2005) and other grouped Epipalaeolithic sites from the Levant.

The absence of the upper body elements may be due to the cut of a recent adjacent pit, although given the position of the skeletal elements and their distance from the boundary of the pit it is also possible that it represents the burial of a partial cadaver. The fusion status and wear patterns indicate burial of an adult, but age and sex are difficult to determine. The tibial length is near the average for Natufian males, but the diaphyseal dimensions are more similar to Natufian females (Table 3). The left calcaneus showed evidence of bony outgrowth/ossification of the achilles tendon insertion with tendon enthesis, an observation suggestive of high strain during life, perhaps from squatting (Molleson 1994). The presence of two polished pebbles (otherwise not found at the site) close to the left patella suggest they were placed as grave goods (Fig. 3). A sample from one of the human bones was submitted for radiocarbon dating but was found to lack collagen, however analysis of charcoal found close to the skeletal remains, provided a date of c. 15.2 - $14.6 \mathrm{ka}$ cal BP (to $2 \sigma$ ) which would be contemporary with the late Geometric Kebaran (Table 1). The abundant lithic assemblage from the pit and adjacent contexts concurs with this date.

Just inside the rock sill at the western side of the cave-mouth, excavations in Phase C revealed a pit (loci 9 and 15 in square $S$ and adjacent areas of $\mathrm{K}, \mathrm{L}, \mathrm{T}$ ) which contained the disarticulated partial skeleton of an infant. This included unfused humerus fragments, both proximal ulnae, a fragment of rib, vertebrae, both femora, proximal tibiae and a distal tibia (Table 2; Fig. 6). In addition to the infant remains, an adult right navicular was also found in 
locus 9 square T as well as three intact adult phalanges in locus 15 squares TL. Two adult metacarpals and a carpal were also recovered from square $\mathrm{K}$. The artefacts found within the main body of the pit are typical of the Natufian and include a bone sickle haft similar in form to an example from the Natufian at Kebara Cave, Mount Carmel. In addition, there were also fragments of a probable small stone pendant and an unusually eroded limestone block with a sinuous groove across its surface which may have served as a grave marker (Garrard and Yazbeck 2013: 21-22). However the pit appears to have cut into Geometric Kebaran levels since at its base there were also many trapeze-rectangles and other characteristic lithics.

\section{Skeletal Remains from Phase B}

On the inside of the rock sill between the centre and the western side of the cave entrance, excavations in Phase $\mathrm{B}$, squares $\mathrm{T}$ and $\mathrm{U}$, revealed a group of pits containing a mixture of disarticulated and semi-articulated human remains. Two ultrafiltration AMS dates within the range c. 9.9 - $9.5 \mathrm{ka}$ cal $\mathrm{BP}$ (to $2 \sigma$ ) (Table 1 ) have been obtained directly from these bones, placing them in the late-Middle to early-Late PPNB period. Apart from a single infant cranial fragment in locus 25 (square T), the bones recovered from the pits (c. 120 in total: Table 2) did not include cranial elements and limb bones were also scarce. The skeletal material appears to represent a mixture of highly disturbed primary burials (possibly with the subsequent selective removal of certain elements) and other material which may represent secondary burials.

In some cases the contents of a single pit contained bones from more than one skeleton: for example, in locus 25 square $\mathrm{T}$ there were partly articulated adult vertebrae and rib fragments, and the remains of an infant less than a year old comprising largely unfused vertebrae and pelvis, left and right femur fragments, an intact tibia, phalanx and a small piece of the skull (Fig. 7; Table 2). In contrast, locus 12 square $T$ contained unfused bone fragments from a single juvenile including a proximal humerus fragment, calcaneus, metatarsal, distal epiphysis and shaft of a femur and lumbar vertebrae. Elsewhere it seems that a scattering and fragmentation of bones may have occurred: for example bones which seem likely to have derived from a single juvenile ( $<18 \mathrm{yrs}$ of age) consisting of phalanges, humerus epiphysis, a pelvis fragment, distal metapodial epiphysis fragment, two proximal femur epiphyses, tibia shaft fragment and unfused vertebrae, were distributed across loci 18 and 28 in squares $\mathrm{T}$ and $\mathrm{U}$.

In addition to the infant and juvenile bones, a variety of adult bones/bone fragments $(n=81)$ were also recovered from the loci 18, 21, 25, 28 and 32 in squares $T$ and $U$, with the majority coming from locus 18 (Table 2 ). The most common components were vertebrae, rib fragments, phalanges, metapodials and carpals/tarsals. There was a notable lack of long bones 
and skull fragments, although fragments of a femur, scapula and radius together with a manubrium were recovered from locus 28 squares TU. The fragments of the distal femur and scapula were relatively small in size perhaps indicating the presence of a female(s). It seems most likely that the majority of the long bones and skulls/mandibles associated with these numerous remnant bones had been separated during their post-mortem history and possibly reburied elsewhere.

It was difficult to judge with confidence how many adult individuals were represented, but one or perhaps two seem most likely, since the bones are distributed across a diversity of loci. It was notable that intact adult cervical, thoracic and lumbar vertebrae from locus 18 square $\mathrm{U}$, displayed frilly osteophytic growth around the centra; while two lumbar vertebrae from locus 28 squares $\mathrm{T}$ and $\mathrm{U}$ showed evidence of disc collapse and pitting on the centrum (Fig. 8). While these observations are only sufficient to determine a minimum of one or two individuals (MNI $1 / 2$ ), it is possible that these remains represent an elderly adult or adults suffering from osteoarthritis, and accustomed to vertebral loading stress. There were no remains suggestive of the presence of young adults above 18 years old.

In summary, examination of bone fusion and relative size indicates that the partial skeletal remains of possibly one or two adults, two juveniles ( $<18 \mathrm{yrs}$ of age; judging from the number of distal femur fragments) and two infants had been incorporated in these burial pits during the Middle to Late PPNB. Interestingly there were no diagnostic lithic tools or cores from this period discovered in association with the skeletal remains although they were found during surface survey of open areas outside the caves.

\section{Human remains from Cave 3}

Very few human bones were encountered in Cave 3 but it is notable that those recovered were from levels radiocarbon dated to the Kebaran, Geometric Kebaran and Natufian (Table 2). In the earliest level, Phase E locus 463, the left mandible of a young adult was found (Fig. 9). The surviving teeth, P4, M1 and M2, showed very little wear which might reflect an age of around 14 years. However the significant gap in the rear jaw, which once held M3, clearly indicates an eruption time of 17 to 21 years. The mandible appeared to be in very good condition and was submitted for radiocarbon dating but was found to lack collagen. However an AMS date on charcoal was obtained for a sample from the adjacent locus 462 which is thought to be an extension of locus 463 . This was $19.2-18.2 \mathrm{ka}$ cal BP (to $2 \sigma$ ) which is contemporary with the late Kebaran (Table 1). Moving upwards through the sequence, in Phase E/D locus 445 (in association with a Geometric Kebaran lithic industry), a worn P4 tooth was found along with a 
partially burnt adult vertebra and rib fragment. Overlying this in Phase D/C locus 441 (also with a Geometric Kebaran industry) several juvenile bones representing the partial remains of a 10-14 years old individual were excavated. These included an unfused left pelvic ilium and ischium, a proximal femur with the head fusing, two metapodial fragments and two phalanges. In a shallow pit close to the top of the sequence (locus 442 in Phase C1) which was AMS dated on charcoal to $14.5-13.8 \mathrm{ka}$ cal BP (to $2 \sigma$ ) making it contemporary with the early Natufian (Table 1 ), an adult scaphoid carpal and phalanx 3 were located, with the latter showing some exostosis. These incomplete human remains suggest that at various stages in the occupational history of Cave 3 , burials may have occurred in the sequence, but were either disturbed or the remains were differentially moved to other locations. It is also possible that these isolated bones may have been brought into the cave from elsewhere.

\section{Discussion}

The rugged, forested coastal mountains of Lebanon provide a very distinctive environment within the central Levant, but until recently very little research had been undertaken on the Epipalaeolithic and Pre-Pottery Neolithic of this region. These were periods in which there were major transformations in the nature of hunter-gatherer communities and the emergence of village based farming societies. The extent to which these developments occurred within this time range in the forested mountain environments of western Lebanon and the degrees of interaction within the wider community are not well understood. It is possible that farming was a later arrival in this area (Cauvin and Cauvin 1993; Garrard 2017). Recent excavations at Moghr el-Ahwal in northern Lebanon are beginning to address some of these issues, and one important aspect is the burial record.

Prior to considering these burials and their wider context, it is interesting to note that the majority of human remains were recovered from Cave 2, which is much smaller than Cave 3, and owing to its low ceiling less suitable for long term occupation by large groups (Edwards et al. 2017). Alongside any occupation, it seems likely that this cave may have been used as a cache and workshop in certain periods but also for the burial of human remains. A survey in 2003 identified lithic evidence for widespread, open-air activities in sheltered areas around Timsah Rock as well as in the caves, and some of the burials could relate to groups who were living largely outside (Garrard and Yazbeck 2004).

\section{Kebaran and Geometric Kebaran}


The earliest evidence for human remains in the Moghr el-Ahwal caves was a fragment of the left mandible of a young adult, from level 463 in Cave 3 (Fig. 9), discovered in an activity area which was radiocarbon dated to the late Kebaran c. 19 ka cal BP. The jaw was found in isolation and clearly derived from another location although the mechanism by which this happened is uncertain.

The most extensive evidence of activities and occupation in both caves dates from the Geometric Kebaran and an intriguing burial of a portion of an articulated human body was found in a well-defined pit immediately behind the high bedrock sill across the entrance of the eastern side of Cave 2 within these levels. The associated lithic industry and radiocarbon date of c. $15 \mathrm{ka}$ cal BP suggests a late Geometric Kebaran age (Figs. 3-5). The burial comprised the lower legs and one foot of an individual, and two polished pebbles appear to have been placed as grave goods adjacent to one of the knees. It is possible that the remainder of the body could have been lost during the cutting of a recent nearby pit, however there is also the possibility that it represents the burial of selected body elements whilst they were still articulated.

Relative to the later periods discussed in this paper, there are very few burials known from the Early and Middle Epipalaeolithic of the Levant and the majority are single primary interments often accompanied by grave goods (Maher et al. 2012). From the Early Epipalaeolithic at Ohalo II, near to the Sea of Galilee, a male skeleton was accompanied by a hammer-stone and incised worked bone (Nadel 1994), while at Kharaneh IV in the Azraq Basin, a pair of gazelle horn cores lay adjacent to the skull of one of two male skeletons (Maher et al. 2012; Muheisen 1988; Rolston 1982). From the Geometric Kebaran at Wadi Mataha in the Petra Basin, a breached ground stone bowl and long flint blade accompanied an adult burial (F81) (Stock et al. 2005) while at Neve David, on the Mount Carmel coast, an adult burial was associated with a stone bowl, grinding slab and breached mortar (Kaufman and Ronen 1988) (see Fig. 1 for the location of sites mentioned in text).

Unusually, at Uyyun al Hammam in north-west Jordan which dates to the Geometric Kebaran, eight separate burial pits containing a minimum of ten individuals have been excavated and these show much greater diversity in burial practice. This includes primary and secondary interments normally associated with grave goods, including ground stone, chipped stone and bone tools, red ochre, and in two cases fox remains. One of the graves (grave VIII), contained several articulated sections of human body, including a cranium with adjoining cervical vertebrae, an articulated upper arm with scapula, and an articulated lower leg. These are likely to have been moved from their original burial place before the soft tissues had completely decayed (Maher 2007; Maher et al. 2011, 2012). It is possible that something of this nature had occurred in the burial of the Geometric Kebaran human remains at Cave 2 Moghr el-Ahwal. 


\section{Natufian}

The disarticulated partial skeleton of an infant including leg and arm bones and vertebrae and ribs, plus a single adult navicular were obtained from a pit on the western side of the Cave 2 entrance (Fig. 6). In the upper level of the pit there were a number of Natufian style artefacts including a portion of a bone sickle haft similar to an example from Kebara Cave in Mount Carmel, as well as fragments of a probable stone pendant. There was also an unusually eroded limestone block with a sinuous groove cutting its surface which might have served as a grave marker (see below). Cave 3 also contained a very small number of adult and juvenile bones fragments in contexts dated to the Natufian.

From the Levant as a whole, there is a massive increase in the number of burials known from the Late Epipalaeolithic relative to earlier periods. Many of these have been found in the larger open air settlements such as Ain Mallaha and Wadi Hammeh 27 in the north Jordan Valley (Bocquentin 2003, 2007; Bocquentin et al. 2013; Perrot and Ladiray 1988; Webb and Edwards 2002; 2013). At the former they were often in pits adjacent to or within abandoned houses, or very occasionally beneath actively used occupation floors. They are also known from a number of cave sites and their adjacent terraces including El Wad, Hayonim, Raqefet and Hilazon Tachtit in the Mount Carmel and Galilee areas (Belfer-Cohen 1988; Grosman et al. 2008; Lengyel et al 2013; Weinstein-Evron 1998). Many of these are single graves but there are also multiple interments and examples of secondary inhumations and skull removal and reburial. There is evidence for temporal trends in some areas although these do not extend across the whole region. Amongst these, secondary inhumations and skull separation are more common in the Late Natufian (Belfer-Cohen 1988; Kuijt 1996; Weinstein-Evron 2009). Body ornamentation including belts, bracelets, necklaces and pendants made from marine shell beads, animal teeth, worked bone and occasionally stone are found in some Early Natufian graves (Belfer-Cohen 1995; Byrd and Monahan 1995). Other rare grave goods include items such as large bone spatulas and animal remains including gazelle horn cores, domestic dogs and tortoise carapaces (Perrot and Ladiray 1988; Grosman et al. 2008). Stone slabs or blocks and occasionally large ground-stone mortars and stone bowls (sometimes breached) as well as cup-marked stones have been found over or adjacent to graves including at Saaidé in the Beqaa Valley of Lebanon (Schroeder 1991). It has been argued that some of these may have served in funerary ritual activities (Rosenberg and Nadel 2014). It is possible that the large stone block with its sinuous grooved surface at Moghr el-Ahwal may have served as a grave marker or in this capacity.

\section{Pre-Pottery Neolithic B}


From the centre-west of the entrance of Cave 2, a mixture of disarticulated and semiarticulated remains of at least one or two adults, two juveniles and two infants were found in a series of shallow pits. Two of the bones were directly dated to c 9.7-9.5 ka cal BP which is equivalent to the late Middle to early Late PPNB elsewhere in the Levant. Apart from one infant, no cranial remains were found and amongst the adults, the limb bones were also scarce. The overall arrangement of the bones suggests a mixture of highly disturbed primary burials in which there had been deliberate removal of crania and some of the larger limb bones, and secondary burial of selected remains. The pits were cut into earlier prehistoric levels and no definite artefacts of PPNB date were recognized although they were found in the open areas outside the caves where there may have been a settlement.

From the wider Levant, the PPNB burial record is very well attested although the vast majority of the data derives from villages rather than from caves (Croucher 2012; Goring-Morris and Belfer-Cohen 2014; Kuijt 2000, 2002; Kuijt and Goring-Morris 2002). One of the exceptions to this is the remarkable Middle PPNB cache of human crania and other remains from Nahal Hemar Cave in the southern Judean Desert (Arensburg and Hershkovitz 1988; BarYosef and Allon 1988). During the Middle PPNB, many of the adolescent and adult burials found in villages, are located under house floors or in courtyard areas and are often primary interments in single graves, without grave goods, but with frequent secondary removal of their skulls. The crania are often found reburied in single or multiple caches, and in some cases they were plastered and painted (Croucher 2012; Kuijt 2000). At the hill-top locality of Kfar Hahoresh in Galilee there is apparent evidence of a special purpose mortuary centre, whilst in the northern Levant there are examples of charnel houses (Croucher 2006, 2012; Goring-Morris 2000). Many of these traditions continued through into the Late PPNB but there were also major changes with the more frequent appearance of grave goods including jewellery and possible adornments on clothing, whilst skull removal and reburial becomes less frequent. The apparent separation of crania in the Middle to Late Pre-Pottery Neolithic burials from Moghr el-Ahwal appears to tie in closely with traditions seen in the broader region.

\section{Conclusions}

The environmental context of Moghr el-Ahwal within the rugged and high elevation coastal mountains of Lebanon is very different from that of other areas of the Levant with burial records dating from the Epipalaeolithic and Pre-Pottery Neolithic. One might expect the forested mountain setting to have led to more cultural isolation and less broad-scale interaction than in 
other regions. At present, there is no archaeological evidence that farming had developed in this area prior to the end of the PPNB, and it is possible that more traditional hunter-gatherer lifestyles persisted in this region (Garrard 2017). However, although the database is extremely limited, the social traditions, as reflected in mortuary practice, do appear to tie in with other areas of the Levant through the periods for which we have evidence. This also applies to stone tool and bone technology which have close parallels with sites in the Galilee, Jordan Valley and Mount Carmel regions over $200 \mathrm{~km}$ to the south.

\section{Acknowledgements}

We owe special thanks to our funding bodies: the British Academy (SG-38007, LRG-39884, LRG-42430), the Council for British Research in the Levant, the Institute of Archaeology at University College London, the Leakey Foundation, the Seven Pillars of Wisdom Trust, the Society of Antiquaries, and the University of London Central Research Fund. In addition the Directors of the Field Project (AG, CY) are very grateful to the Directorate of Antiquities in Lebanon for permission to undertake the field work and to members of the excavation team and the local community for all their support. We would like to thank Stuart Laidlaw and Joe Roe for help with the illustrations. 


\section{References}

Arensburg, B. and Hershkovitz, I. 1988. Nahel Hemar Cave: Neolithic Human Remains. Atiqot 18: $50-58$.

Bar-Yosef, O. and Alon, D. 1988. Nahel Hemar Cave: the Excavations. Atiqot 18: 1-30.

Belfer Cohen, A. 1988. The Natufian graveyard in Hayonim Cave. Paléorient 14 (2): 297-308.

Belfer-Cohen, A. 1995. Rethinking social stratification in the Natufian culture: the evidence from burials. In, Campbell, S. and Green, A. (eds), The Archaeology of Death in the Ancient Near East: 9-16. Oxford: Oxbow.

Bergman, C. and Stringer, C. 1989. Fifty years after: Egbert an early Upper Palaeolithic juvenile from Ksar Akil, Lebanon. Paléorient 15 (2): 99-111.

Bocquentin, F. 2003. Pratiques funéraires, paramètres biologiques et identités culturelles au Natoufien: une analyse archéo-anthropologique. Doctoral thesis University of Bordeaux 1.

Bocquentin, F. 2007. A final Natufian population: health and burial status at Eynan-Mallaha. In, Faerman, M., Horwitz, L. K., Kahana, T. and Zilberman, U. (eds), Faces from the past: diachronic patterns in the biology of human populations from the Eastern Mediterranean. Papers in honour of Patricia Smith: 66-81. Oxford: British Archaeological Reports, International series 1603.

Bocquentin, F., Cabellos, T. and Samuelian, N. 2013. Graves in context: field anthropology and the investigation of interstratified floors and burials. In, Bar-Yosef, O. and Valla, F. R. (eds), Natufian Foragers in the Levant. Terminal Pleistocene Social Changes in Western Asia: 185-192. Ann Arbor: International Monographs in Prehistory.

Bocquentin, F. and Garrard, A. 2016. Natufian collective burial practice and cranial pigmentation: a reconstruction from Azraq 18 (Jordan). Journal of Archaeological Science: Reports 10: 693-702. 
Boyd, B. 2001. The Natufian burials from el-Wad: beyond issues of social differentiation. Journal of the Israel Prehistoric Society 31: 185-200.

Byrd, B.F. and Monahan, C.M. 1995. Death, mortuary ritual and Natufian social structure. Journal Anthropological Archaeology 14: 251-87.

Cauvin, M.C. and Cauvin, J. 1993. La sequence néolithique PPNB au Levant Nord. Paléorient, 19 (1): 23-28.

Copeland, L. and Wescombe, P. J. 1965. Inventory of Stone Age sites in Lebanon. Mélanges de l’Université Saint-Joseph 41: 30-175.

Copeland, L. and Yazbeck, C. 2002. Inventory of Stone Age sites in Lebanon. Part III, Additions and Revisions, 1967-2001. Melanges de l'Université Saint-Joseph, 55 (1997-1998): 121-325.

Croucher, K. 2006. Death, display and performance: a discussion of the mortuary remains at Çayönü Tepesi, southeast Turkey. In, Georgiadis, M. and Gallou, C. (eds), The Archaeology of Cult and Death: 11-44. Budapest: Archaeolingua.

Croucher, K. 2012. Death and dying in the Neolithic Near East. Oxford: Oxford University Press.

Douka, K., Bergman, C.A., Hedges, R.E.M., Wesselingh, F.P. and Higham, T.F.G. 2013. Chronology of Ksar Akil (Lebanon) and implications for the colonization of Europe by anatomically modern human, PLoS ONE, 8(9): e72931.

Edwards, Y., Garrard, A. and Yazbeck, C. 2017. Hunting and trapping strategies in the coastal mountains of northern Lebanon during the Epipalaeolithic. Levant, 49: DOI:

$10.1080 / 00758914.2017 .1408217$

Faerman, M., Horwitz, L. K., Kahana, T. and Zilberman, U. (eds) 2007. Faces from the past: diachronic patterns in the biology of human populations from the Eastern Mediterranean. Papers in honour of Patricia Smith. Oxford: British Archaeological Reports, International series 1603. 
Garrard A.N. (2017) The Epipalaeolithic and Pre-Pottery Neolithic of Lebanon. In Y. Enzel and O. Bar-Yosef (eds.) Quaternary of the Levant. Environments, Climate Change and Humans: 691-697. Cambridge: Cambridge University Press.

Garrard, A. and Yazbeck, C. 2004. Qadisha Valley Prehistory Project (Northern Lebanon). Results of 2003 Survey Season. Bulletin d'Archéologie et d'Architecture Libanaises 8: 5-46.

Garrard, A. and Yazbeck, C. 2008. Qadisha Valley Prehistory Project (Lebanon). The 2004-2008 Excavations at Moghr el-Ahwal. Bulletin d'Archéologie et d'Architecture Libanaises 12: 5-15.

Garrard, A. and Yazbeck, C. 2013. The Natufian of Moghr el-Ahwal in the Qadisha Valley, Northern Lebanon. In, Bar-Yosef, O. and Valla, F. R. (eds), Natufian Foragers in the Levant. Terminal Pleistocene Social Changes in Western Asia: 17-27. Ann Arbor: International Monographs in Prehistory.

Goren, N. and Bar-Yosef, O. 1973. Natufian remains in the Levant. Paléorient 1 (1): 49-86.

Goring-Morris, A. N. 2000. The Quick and the Dead: the social context of Aceramic Neolithic mortuary practices as seen from Kfar Hahoresh. In, Kuijt, I. (ed.), Life in Neolithic Farming Communities. Social Organization, Identity and Differentiation: 103-136. New York: Kluwer Academic/Plenum.

Goring-Morris, A. N. and Belfer-Cohen, A. 2014. Different strokes for different folks. Near Eastern Neolithic Mortuary Practices in Perspective. In, Hodder I. (ed.), Religion at Work in a Neolithic Society: Vital Matters: 35-57. Cambridge: Cambridge University Press.

Grossman, L., Munro, N. and Belfer-Cohen, A. 2008. A 12,000 year old Shaman burial from the southern Levant (Israel). Proceedings of the National Academy of Sciences 105: 17665-17669.

Haïdar-Boustani, M. and Ibáñez, J. J. 2011. Nouveaux travaux archéologiques à Tell Labwé Sud (Béqa' nord) Campague 2011: rapport préliminaire. Bulletin d'Archéologie et d'Architecture Libanaises 15: 21-44.

Hershkovitz, I., Spiers, M.S., Frayer, D., Nadel, D., Wish-Baratz, S. and Arensburg, B. 1995. Ohalo II: a 19,000 year old skeleton from a water-logged site at the Sea of Galilee Israel. American Journal of Physical Anthropology 96: 215-234. 
Kaufman, D. and Ronen, A. 1988. La sépulture Kébarienne Géométrique de Neve David, Haifa, Israël. L'Anthropologie 91: 335-342.

Kirkbride, D. 1969. Early Byblos and the Beqaa. Melanges de l'Université SaintJoseph 45: 45-60.

Kuijt, I. 1996. Negotiating equality through ritual: a consideration of Late Natufian and Prepottery Neolithic A period mortuary practices. Journal of Anthropological Archaeology 15: 313-336.

Kuijt, I. 2000. Keeping the Peace: Ritual, Skull Caching, and Community Integration in the Levantine Neolithic. In, Kuijt, I. (ed.), Life in Neolithic Farming Communities. Social Organization, Identity and Differentiation: 137-162. New York: Kluwer Academic/Plenum.

Kuijt, I. 2002. Place, death, and the transmission of social memory in early agricultural communities of the Near Eastern Pre-Pottery Neolithic. In, Chesson, M. S. (ed.), Social Memory, Identity, and Death: Anthropological Perspectives on Mortuary Rituals: 80-99. Archeological Papers of the American Anthropological Association 10.

Kuijt, I. and Goring-Morris, A. N. 2002. Foraging, farming and social complexity in the PrePottery Neolithic of the south-central Levant: A review and synthesis. Journal of World Prehistory 16 (4): 361-440.

Lengyel, G., Nadel, D. and Bocquentin, F. 2013. The Natufian at Raqefet cave. In, Valla, F. and Bar-Yosef, O. (eds), Natufian Foragers in the Levant. Terminal Pleistocene Social Changes in Western Asia : 478-504. Ann Arbor: International Monographs in Prehistory.

Maher, L.A. 2007. Microliths and mortuary practices: new perspectives on the Epipalaeolithic in northern and eastern Jordan. In, Levy, T. E., Daviau, P. M. M., Younker, R.W. and Shaer, M, (eds), Crossing Jordan: North American contributions to the archaeology of Jordan: 195-202. London: Equinox. 
Maher, L.A., Stock, J.T., Finney, S., Heywood, J., Miracle, P.and Banning, E.B. 2011. Uyun alHammam. A unique human-fox burial from a pre-Natufian cemetery in the Levant (Jordan). PLoS ONE 6 (1): e15815.

Maher, L.A., Richter, T. and Stock, J.T 2012. The Pre-Natufian Epipaleolithic: Long-Term Behavioral Trends in the Levant. Evolutionary Anthropology 21: 69-81.

Metni, M. 1999. A re-examination of a proposed Neanderthal maxilla from Ksar 'Akil rock shelter, Antelias, Lebanon. American Journal of Physical Anthropology, Supplement 28: 202.

Molleson, T. 1994. The Eloquent Bones of Abu Hureyra. Scientific American 271: 70-75.

Muheisen, M. 1988. The Epipalaeolithic phases of Kharaneh IV. In, Garrard, A. and Gebel, HG. (eds), The Prehistory of Jordan: 353-367. Oxford: British Archaeological Reports, International Series 396.

Nadel, D. 1994. Levantine Upper Palaeolithic - Early Epipalaeolithic burial customs: Ohalo II as a case study. Paléorient 20 (1): 113-121.

Perrot, J. and Ladiray, D. 1988. Les Hommes de Mallaha (Eynan) Israel, I. Les Sépultures. Mémoires et Travaux du Centre de Recherche Français de Jérusalem 7. Paris: Association Paléorient.

Rolston, S. L. 1982. Two prehistoric burials from Qasr Kharaneh. Annual of the Department of Antiquities of Jordan, 26: 221-229.

Rosenberg, D. and Nadel, D. 2014. The sounds of pounding. Boulder mortars and their significance to Natufian burial customs. Current Anthropology, 55: 784-812.

Schroeder, B. 1991. Natufian in the Central Béqaa Valley, Lebanon. In, Bar-Yosef O. and Valla F. R. (eds), The Natufian Culture in the Levant: 43-80. Ann Arbor: International Monographs in Prehistory.

Solivères, O. 1975-1977. Restes humaines Natoufiens de Jebel Saaidé (Épipaléolithique du Liban). Paléorient 3: 293-294. 
Stock, J.T., Pfeiffer, S.K., Chazan, M. and Janetski, J. 2005. F-81 skeleton from Wadi Mataha, Jordan and its bearing on human variability in the Epipaleolithic of the Levant. American Journal of Physical Anthropology 128: 453-465.

Vallois, H. V. 1957. Le squelette de foetus humain fossile d'Antélias (Liban). Quaternaria 4: 112.

Waechter, J. d'A. 1975. Lebanon. In, Oakley, K. P., Campbell, B. G. and Molleson, T. K. (eds), Catalogue of Fossil Hominids. Part III: Americas, Asia, Australasia: 161-165. London: The British Museum (Natural History).

Webb, S.G. and Edwards, P.C. 2002. The Natufian human sheletal remains from Wadi Hammeh 27 (Jordan). Paléorient 28 (1): 103-124.

Webb, S.G. and Edwards, P.C. 2013. The human skeletal remains and their context. In, P.C. Edwards (ed.), Wadi Hammeh 27, an Early Natufian Settlement at Pella in Jordan: 367-382. Leiden, Brill.

Weinstein-Evron, M. 1998. Early Natufian el-Wad Revisited. Liège: Etudes et Recherches Archéologiques de l’Université de Liège (ERAUL 77). 


\section{Figure}

Figure 1. Location of Moghr el-Ahwal and other sites mentioned in the text. 1: Moghr elAhwal (EP, PPN); 2: Tabarja (PPN) 3: Ksar Akil (EP), Abri Bergy (EP), Antelias (EP); 4: Saaidé I, II (EP); 5: Tell Labwé South (PPN); 6: Mallaha (EP); 7: Kfar Hahoresh (PPN); 8: Hayonim (EP), Hilazon Tachtit (EP); 9: Neve David (EP); 10. El Wad (EP); 11. Kebara (EP); 12. Raqefet (EP); 13: Ohalo II (EP); 14: Wadi Hammeh 27 (EP); 15: Uyyun en Hammam (EP); 16: Kharaneh IV (EP); 17: Nahel Hemar (PPN); 18: Wadi Mataha (EP). Note that EP = Epipalaeolithic; PPN = Pre-Pottery Neolithic.

Figure 2. Moghr el-Ahwal Cave 2 and Cave 3 grid plans used during excavation. In Cave 3, Area C was selected for investigation since Areas A, B and D were badly disturbed. Note the plans are at different scales.

Figure 3. Moghr el-Ahwal Cave 2. The Late Geometric Kebaran burial from Phase D (locus 30, square Y) at early stage of excavation. The base of the high bedrock entrance sill can be seen at the back of the burial pit. Two polished pebbles in burial pit can be seen in centre left.

Figure 4. Moghr el-Ahwal Cave 2. The lower limbs of the Late Geometric Kebaran burial from Phase D (locus 30, square Y) including the tibia and fibula of both legs together with the astragalus, calcaneum and tarsals of the left leg. The left patella and distal femur condyles are also shown. Additional small fragments of the right femur were recovered but are not shown.

Figure 5. Moghr el-Ahwal Cave 2. The Late Geometric Kebaran burial from Phase D (locus 30, square Y). CT scans of right and left fibula and tibia, omitting the fractured condylar ends.

Figure 6. Moghr el-Ahwal Cave 2 Phase C (loci 9 and 15, square S): disarticulated partial skeleton of an infant.

Figure 7. Moghr el-Ahwal Cave 2 Phase B (locus 25, square T): disarticulated partial skeleton of an infant (dated to Mid to Late PPNB).

Figure 8. Moghr el-Ahwal Cave 2 Phase B (locus 28, squares T and U): two adult lumbar vertebrae showing disc collapse and centrum pitting (dated to Mid to Late PPNB) 
Figure 9. Moghr el-Ahwal Cave 3 Phase E (locus 463): left mandible of a young adult.

\section{Tables}

Table 1. Radiocarbon dates from prehistoric levels at Moghr el-Ahwal Caves 2 and 3. Note that the phase lettering system used for each cave is independent.

Table 2. Table of human remains recorded from Caves 2 and 3 at Moghr el-Ahwal. Elements bold and underlined are thought to relate to one individual.

Table 3. Length of tibia and position of nutrient foramen from the skeleton buried during the late Geometric Kebaran in Moghr el-Ahwal Cave 2 Phase D. This measurement is compared with Epipaleolithic specimens recovered from various locations in the Levant: Ohalo II - Sea of Galilee (Hershkovitz et al 1995); Kharaneh IV - Eastern Jordan (Rolston 1982); Wadi Mataha Southern Jordan (Stock et al 1995); and with grouped Natufian specimens from the Southern Levantine sites Nahel Oren, Hayonim, Mallaha (Eynan) and Raqefet. 


\begin{tabular}{|l|c|c|l|l|l|l|l|}
\hline Cave \& Phase & Locus & Square & Material & Lab Code & 14C Date & Cal. Date - 1 $\mathbf{~}$ & Cal. Date - $\mathbf{\sigma}$ \\
\hline \multicolumn{1}{|c|}{ CAVE 2 } & & & & & & & \\
\hline Phase B & 18 & $\mathrm{U}$ & Charcoal & Wk 20841 & $7,610+-42 \mathrm{BP}$ & $8,430-8,375 \mathrm{BP}$ & $8,520-8,340 \mathrm{BP}$ \\
\hline Phase B & 18 & $\mathrm{~T}$ & Human Bone & OxA 18862 & $8,517+-39 \mathrm{BP}$ & & $9,595-9,524 \mathrm{BP}$ \\
\hline Phase B & 18 & $\mathrm{U}$ & Human Bone & OxA 18863 & $8,710+-45 \mathrm{BP}$ & & $9,871-9,598 \mathrm{BP}$ \\
\hline Phase D & 30 & $\mathrm{Y}$ & Charcoal & Wk 20843 & $12,664+-63 \mathrm{BP}$ & $15,090-14,800 \mathrm{BP}$ & $15,250-14,600 \mathrm{BP}$ \\
\hline \multicolumn{1}{|c|}{ CAVE 3 } & & & & & & & \\
\hline Phase C1 & 442 & $\mathrm{Cd}$ & Charcoal & OxA 20551 & $12,230+-75 \mathrm{BP}$ & $14,190-13,989 \mathrm{BP}$ & $14,463-13,859 \mathrm{BP}$ \\
\hline Phase D & 456 & $\mathrm{Cb}$ & Charcoal & OxA 20673 & $13,585+-55 \mathrm{BP}$ & $16,357-15,969 \mathrm{BP}$ & $16,578-15,799 \mathrm{BP}$ \\
\hline Phase E & 462 & $\mathrm{C}$ & Charcoal & OxA 20552 & $15,750+-75 \mathrm{BP}$ & $19,019-18,896 \mathrm{BP}$ & $19,123-18,827 \mathrm{BP}$ \\
\hline Phase F & 461 & $\mathrm{C}$ & Charcoal & OxA 20674 & $17,220+-70 \mathrm{BP}$ & $20,447-20,232 \mathrm{BP}$ & $20,577-20,091 \mathrm{BP}$ \\
\hline
\end{tabular}

Table 1 


\begin{tabular}{|c|c|c|c|c|c|c|c|c|c|c|c|c|c|}
\hline $\begin{array}{l}\text { CAVE \& } \\
\text { PHASE }\end{array}$ & LOCUS & age & $\begin{array}{c}\text { bones/ } \\
\text { fragment } \\
s\end{array}$ & skull & $\begin{array}{l}\text { upper } \\
\operatorname{limb}\end{array}$ & $\begin{array}{l}\text { lower } \\
\text { limb }\end{array}$ & $\begin{array}{c}\text { sternum/ } \\
\text { coccyx }\end{array}$ & $\begin{array}{l}\text { scapula/ } \\
\text { pelvis }\end{array}$ & $\begin{array}{l}\text { wrist/ } \\
\text { ankle } \\
\text { bones }\end{array}$ & $\begin{array}{c}\text { metapodi } \\
\text { a }\end{array}$ & $\begin{array}{c}\text { phalange } \\
\mathrm{s}\end{array}$ & $\begin{array}{c}\text { vertebrae } \\
/ \quad \text { ribs }\end{array}$ & MNI \\
\hline \multicolumn{14}{|l|}{ CAVE 2} \\
\hline \multirow{12}{*}{ Cave $2 \mathrm{Ph} B$} & 12 & juvenile & 8 & 0 & 1 & 1 & 0 & 0 & 2 & 1 & 0 & 2 & $1 ?$ \\
\hline & 25 & adult & 39 & 0 & 0 & 0 & 0 & 0 & 0 & 0 & 1 & 38 & \\
\hline & 25 & infant & 20 & 1 frag & 0 & 3 & 1 & 1 & 0 & 0 & 1 & 7 & 1 \\
\hline & 18 & juvenile & $13+$ & 0 & 1 & 2 & 0 & 0 & 0 & 2 & 3 & 6 frags & 1 \\
\hline & 18 & adult & 16 & 0 & 0 & 0 & 0 & 0 & 2 & 3 & 3 & 6 & \\
\hline & 21 & adult & 1 & 0 & 0 & 0 & 0 & 0 & 0 & 0 & 1 & 0 & \\
\hline & 28 & infant & 1 & 0 & 0 & 0 & 0 & 1 & 0 & 0 & 0 & 0 & \\
\hline & 28 & juvenile & 10 & 0 & 1 & 3 & 0 & 0 & 0 & 0 & 0 & 4 & 1 \\
\hline & 28 & adult small & 2 & 0 & 0 & 1 & 0 & 1 & 0 & 0 & 0 & 0 & 1 \\
\hline & 28 & adult & 8 & 0 & 1 & 1 & 1 & 0 & 0 & 1 & 0 & 4 & \\
\hline & 32 & juvenile & 3 & 0 & 0 & 0 & 0 & 0 & 0 & 0 & 1 & 2 & \\
\hline & 32 & adult & 12 & 0 & 0 & 0 & 0 & 0 & 3 & 0 & 1 & 8 & $1 ?$ \\
\hline \multirow[t]{4}{*}{ Cave 2 Ph C } & 9 & infant & 2 & 0 & 1 & 1 & 0 & 0 & 0 & 0 & 0 & 0 & \\
\hline & 9 & adult & 1 & 0 & 0 & 0 & 0 & 0 & 1 & 0 & 0 & 0 & \\
\hline & 15 & infant & 14 & 0 & 2 & 3 & 0 & 0 & 0 & 0 & 0 & 8 & 1 \\
\hline & 15 & adult & 6 & 0 & 0 & 0 & 0 & 0 & 1 & 2 & 3 & 0 & \\
\hline Cave 2 Ph D & 30 & adult & 19 & 0 & 0 & 6 & 0 & 0 & 7 & 0 & 1 & 1 & 1 \\
\hline \multirow[t]{2}{*}{ Cave $2 \mathrm{Ph} \mathrm{E}$} & 5 & infant & 1 & 0 & 0 & 0 & 0 & 0 & 0 & 0 & 0 & 1 & \\
\hline & 5 & adult & 1 & 0 & 0 & 0 & 0 & 0 & 0 & 0 & 1 & 0 & \\
\hline \multicolumn{14}{|l|}{ CAVE 3} \\
\hline Cave $3 \mathrm{Ph}$ C1 & 442 & adult & 2 & 0 & 0 & 0 & 0 & 0 & 1 & 0 & 1 & 0 & \\
\hline \multirow[t]{2}{*}{$\begin{array}{l}\text { Cave 3 Ph } \\
\text { D/C }\end{array}$} & 441 & adult & 0 & 0 & 0 & 0 & 0 & 0 & 0 & 0 & 1 & 0 & \\
\hline & 441 & juvenile & 7 & 0 & 0 & 1 & 0 & 1 & 0 & 2 & 2 & 0 & $1 ?$ \\
\hline $\begin{array}{l}\text { Cave } 3 \mathrm{Ph} \\
\mathrm{E} / \mathrm{D}\end{array}$ & 445 & adult & 3 & 1 tooth & 0 & 0 & 0 & 0 & 0 & 0 & 0 & 2 & \\
\hline Cave $3 \mathrm{Ph} \mathrm{E}$ & 463 & $\begin{array}{l}\text { young } \\
\text { adult }\end{array}$ & 1 & 1 mand & 0 & 0 & 0 & 0 & 0 & 0 & 0 & 0 & \\
\hline
\end{tabular}

Table 2 


\begin{tabular}{|l|l|l|l|l|l|}
\hline Sites & Period & $\begin{array}{c}\text { Tibia max } \\
\text { length } \\
\mathbf{m m} .\end{array}$ & $\begin{array}{l}\text { ant-post diam. } \\
\text { nutrient foramen } \\
\mathbf{m m} .\end{array}$ & $\begin{array}{l}\text { medio-lat diam. } \\
\text { nutrient foramen } \\
\mathbf{m m} .\end{array}$ & $\begin{array}{l}\text { circumference } \\
\text { nutrient foramen } \\
\mathbf{m m} .\end{array}$ \\
\hline Moghr el Ahwal Cave 2 & Mid EpiPal & 369 & 33.18 & 17.61 & 85 \\
Ohalo II H2 male & Early EpiPal & 387 & 38.93 & 21.78 & 97 \\
Kharaneh IV male & Early EpiPal & 372 & 40.34 & 21.09 & 98 \\
Wadi Mataha F-81 & Mid EpiPal & 330 & 37.72 & 22.67 & 94 \\
mean South Levant males & Natufian & 363.2 & $37.16(n=12)$ & $23.41(n=11)$ & $96(n=7)$ \\
mean South Levant females & Natufian & 334.2 & $33.16(n=5)$ & $23.39(n=5)$ & $82(n=4)$ \\
\hline
\end{tabular}

Table 3 


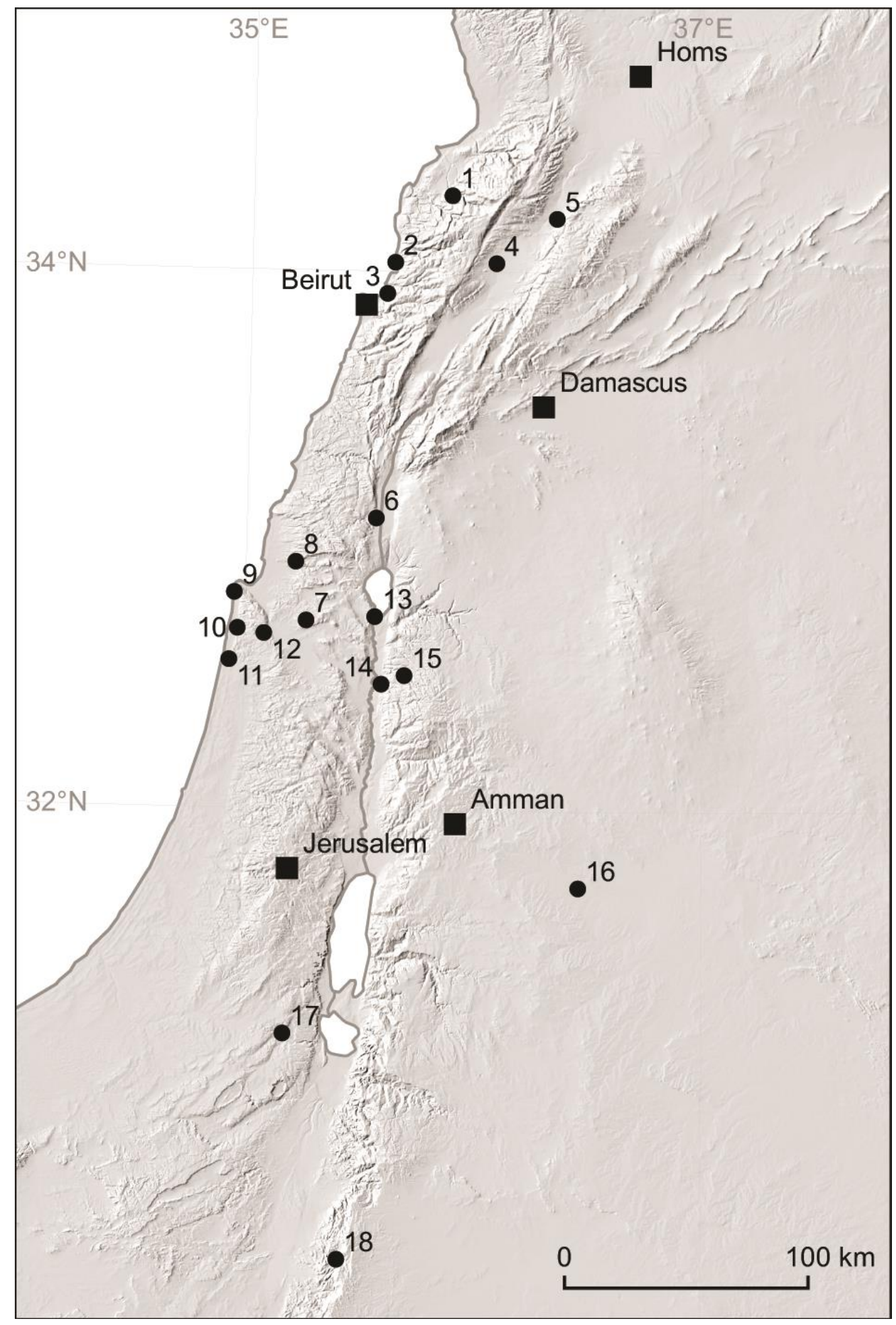

Figure 1 


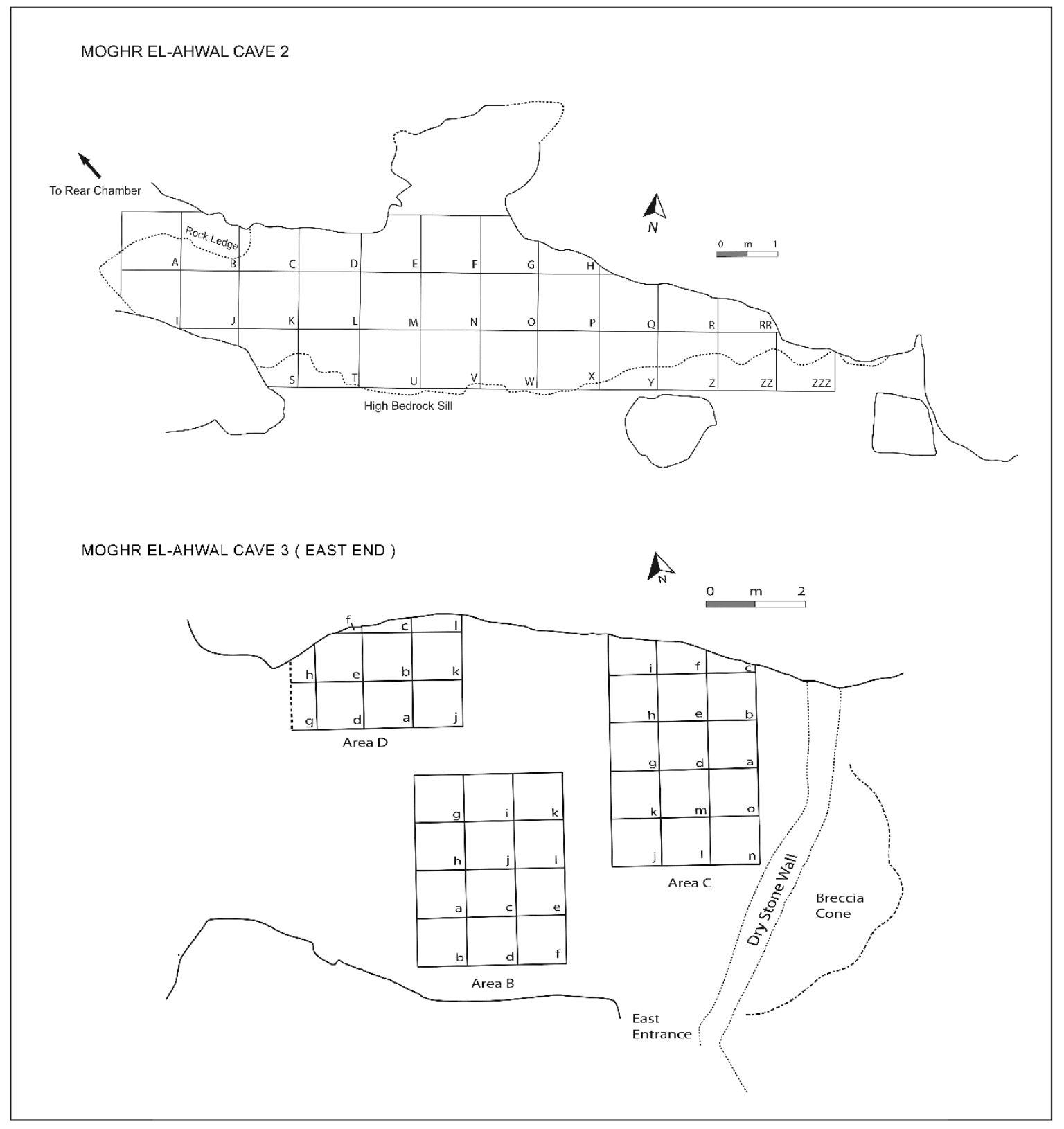

Figure 2 


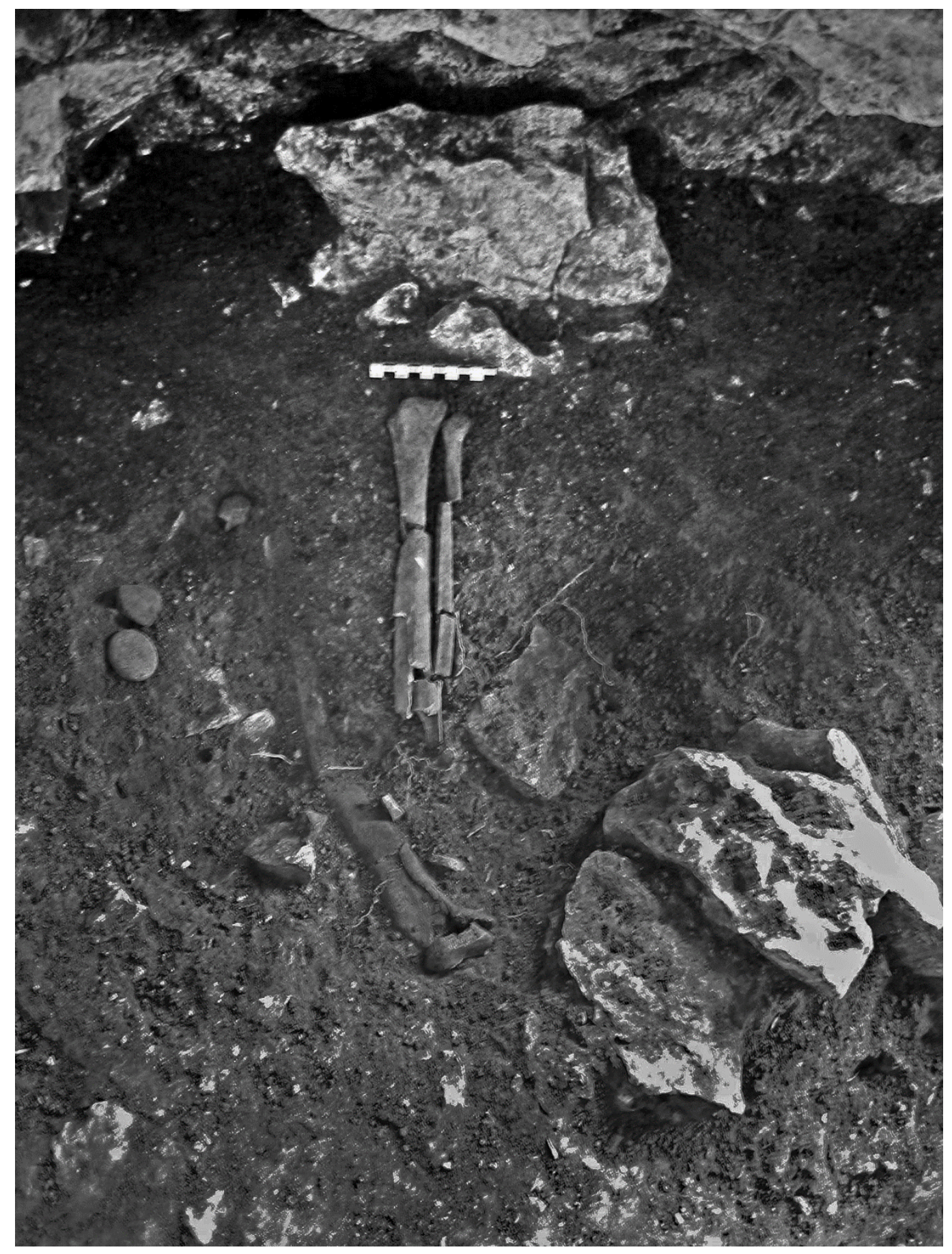

Figure 3 

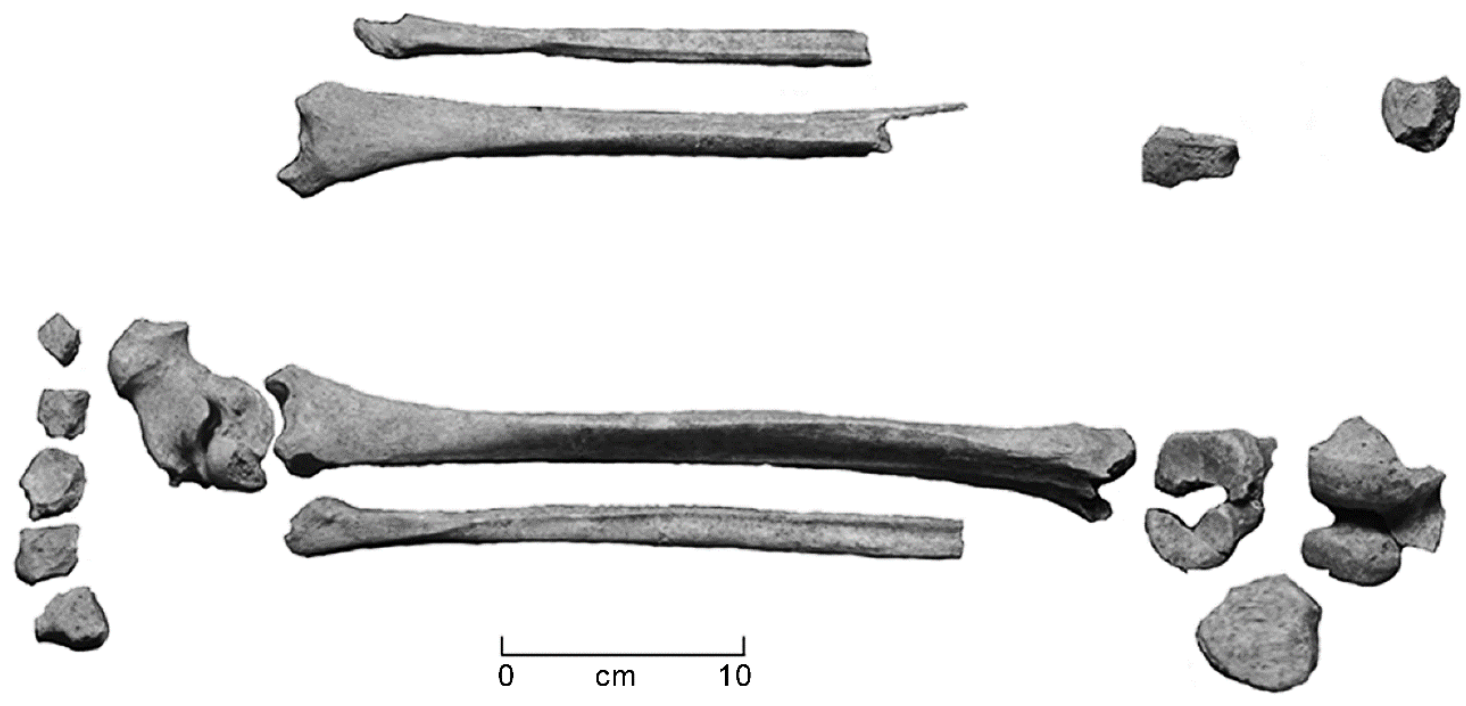

Figure 4

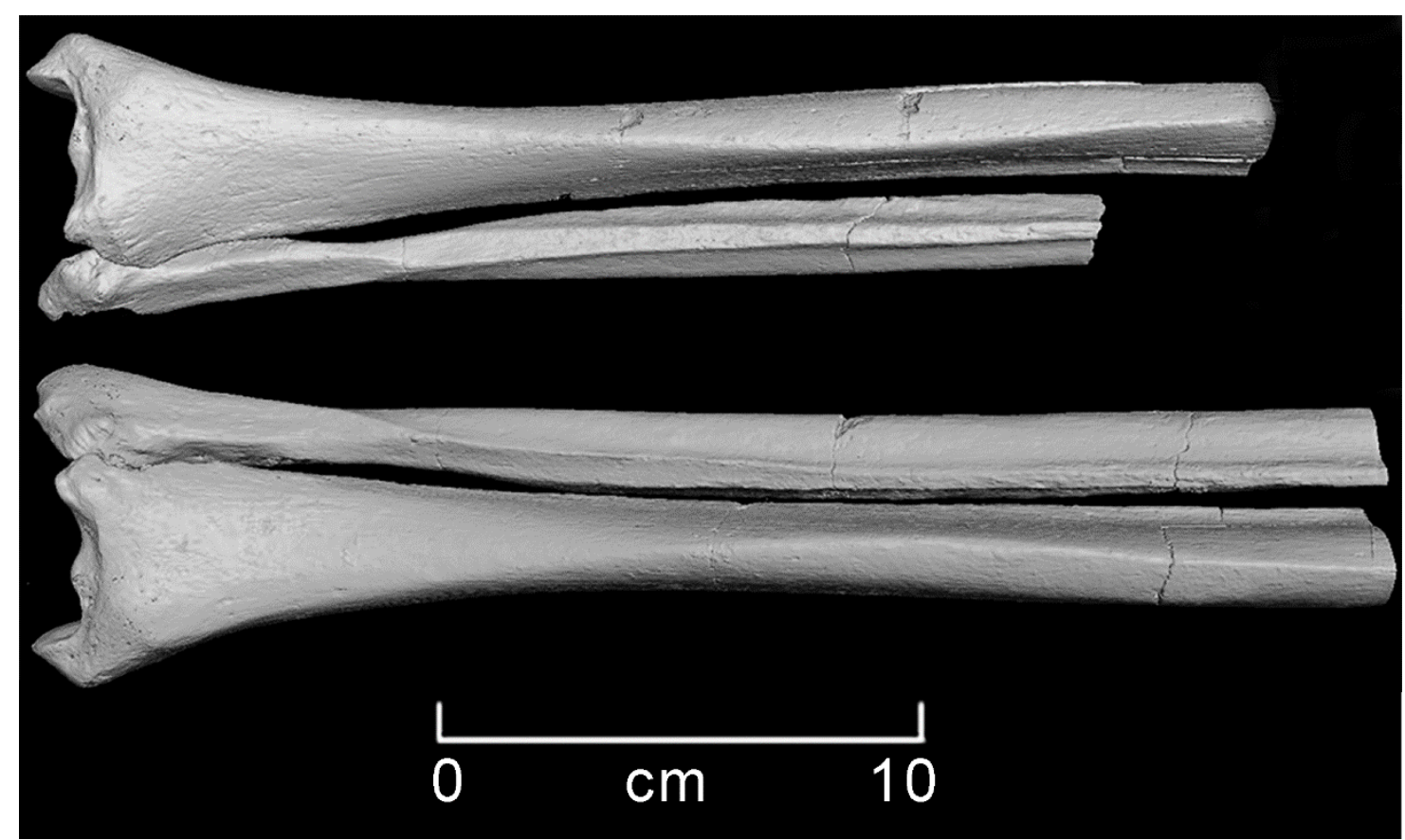

Figure 5 


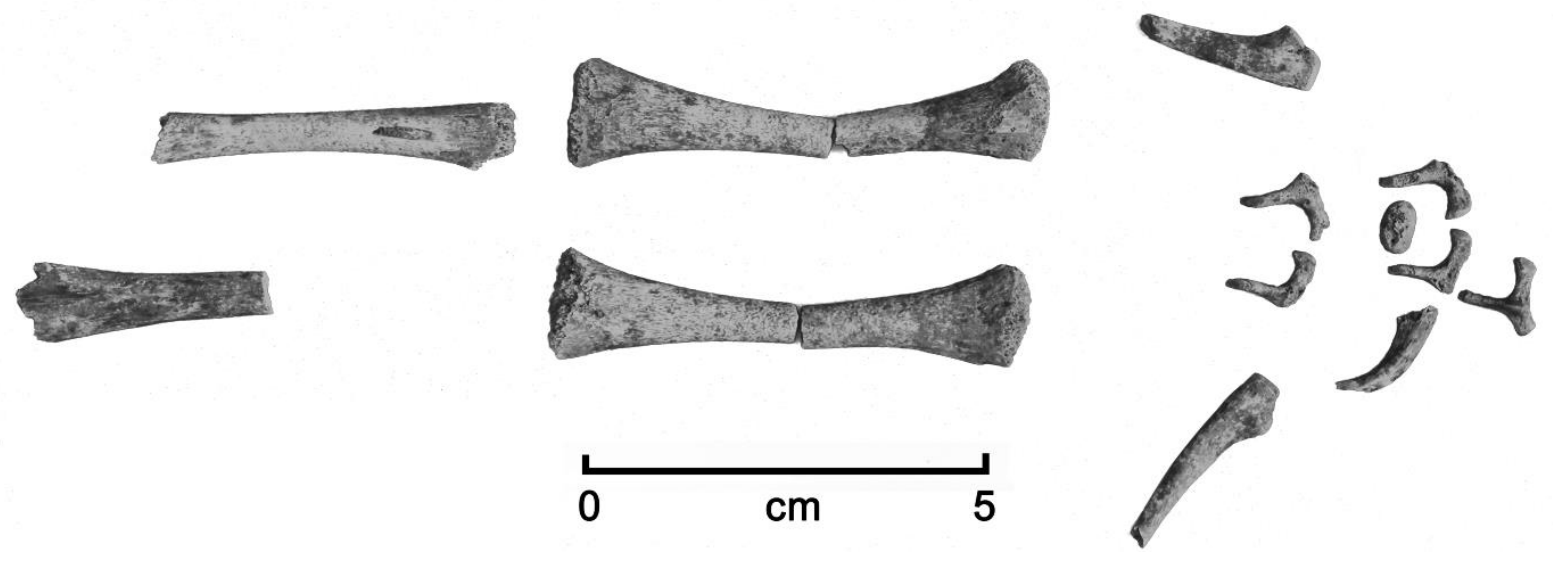

Figure 6

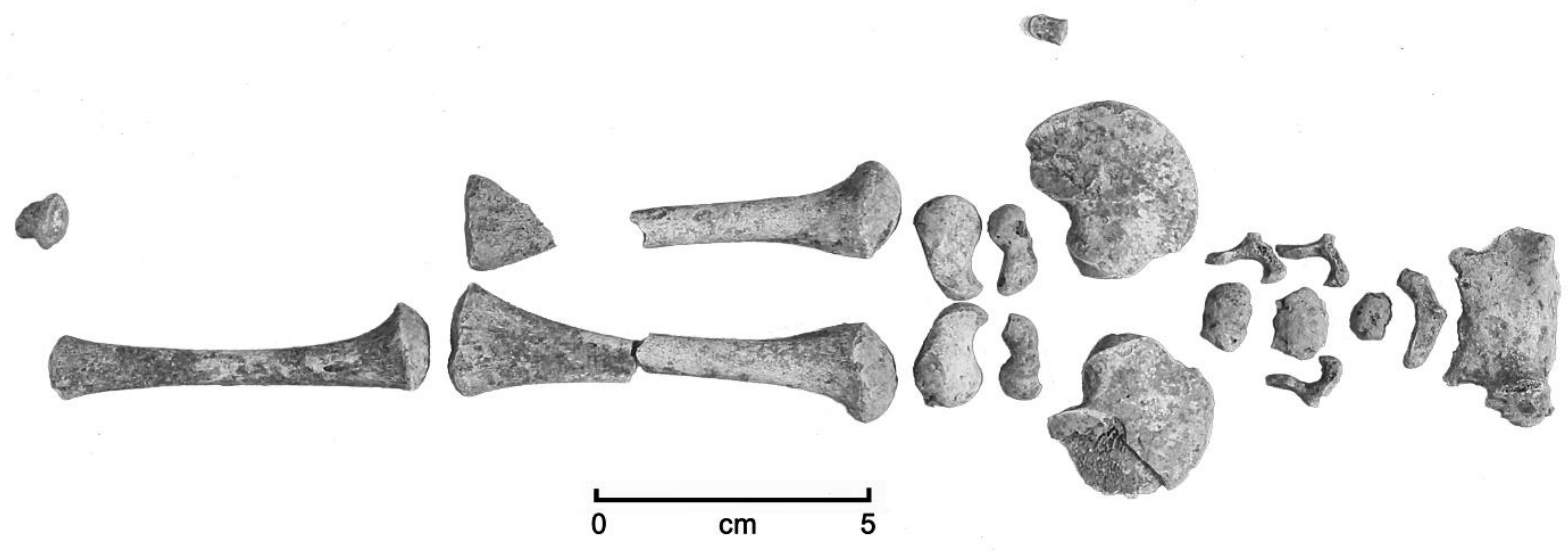

Figure 7 

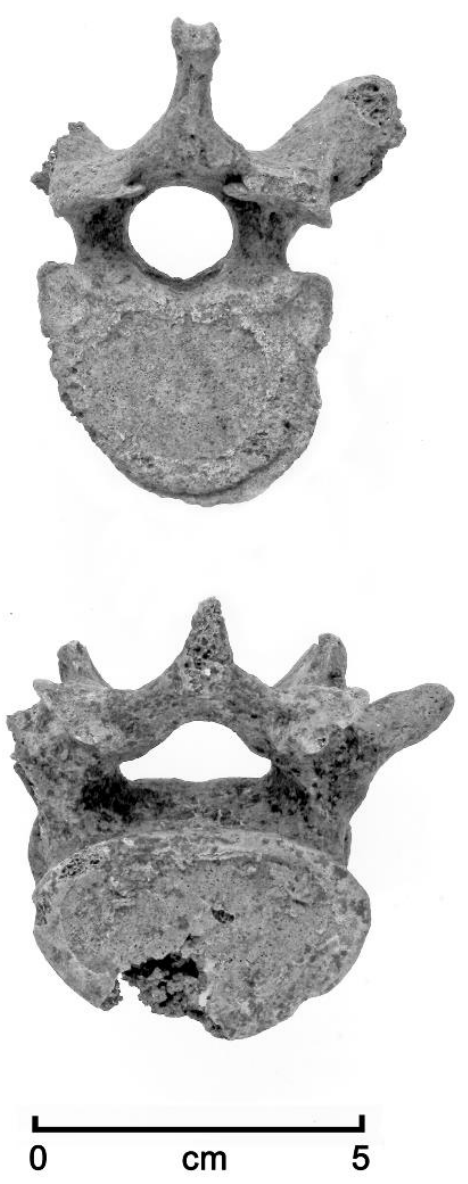

Figure 8 


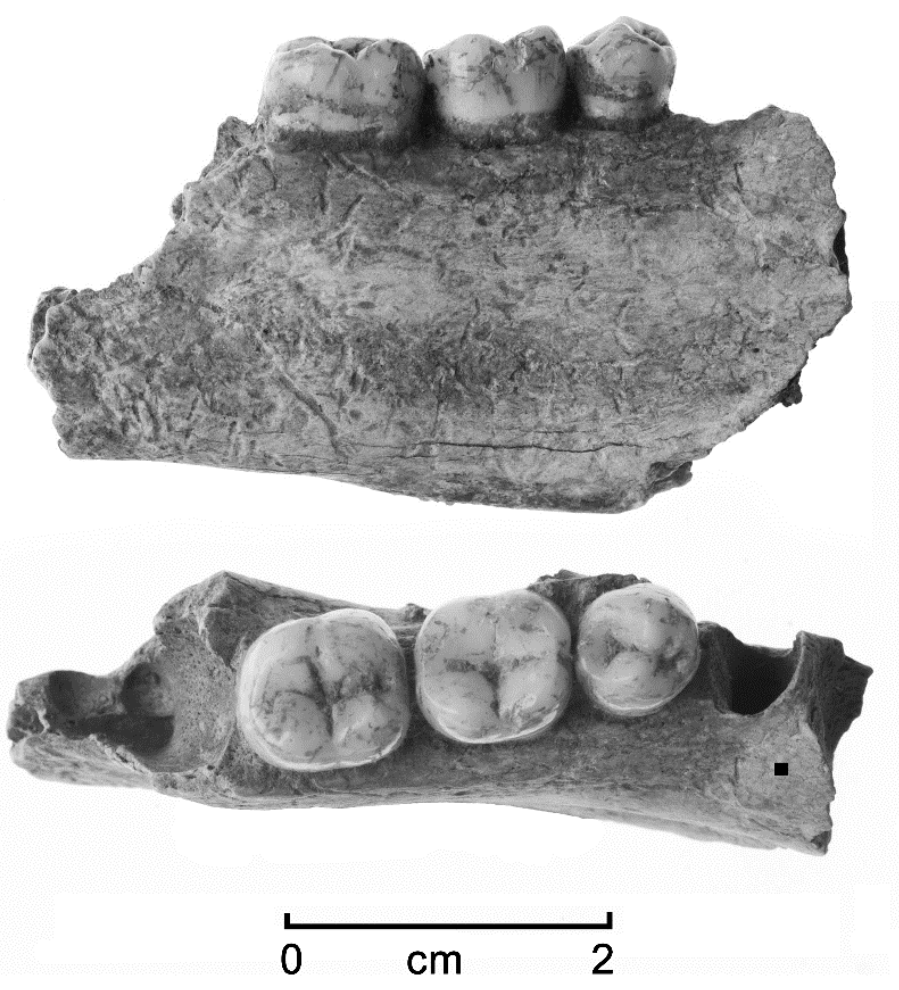

Figure 9 